\title{
Ornithine Decarboxylase Expression in the Small Intestine of Broilers Submitted to Feed Restriction and Glutamine Supplementation
}

Q Author(s)
Fischer da Silva AV ${ }^{1}$
Borges $\mathrm{SA}^{3}$
Maiorka $\mathrm{A}^{2}$
Givisiez PEN ${ }^{4}$
Rocha $\mathrm{C}^{5}$
Macari M ${ }^{4}$
1 Profa UFPR/PR, SCB, Dept. Fisiologia.
2 Prof UFPR/PR, SCA, Dept. Zootecnia.
3 Prof UTP/PR, Faculdade de Ciências

Biológicas e da Saúde.
4 UNESP, FCAV - Jaboticabal/SP.
5 Animal Science undergraduate student
UFPR/PR.

Mail Address

Ana Vitória Fischer da Silva

Depto de Fisiologia - SCB/UFPR

Centro Politécnico

Jardim das Américas

81.531-900. Curitiba, PR, Brazil.

E-mai: avitoria@ufpr.br

Keywords

Feed nutrition, glutamine, intestinal mucosa, mucosa growth, ornitine decarboxylase.

\section{ABSTRACT}

Six hundred and forty one-day-old Cobb male broilers were used to evaluate ornithine decarboxylase (ODC) expression in the mucosa of the small intestine. Birds were submitted to early feed restriction from 7 to 14 days of age. The provided feed was supplemented with glutamine. A completely randomized design with a $2 \times 2$ factorial arrangement was used (with or without glutamine, with or without feed restriction). Restricted-fed birds were fed at 30\% the amount of the ad libitum fed group from 7 to 14 days of age. Glutamine was added at the level of $1 \%$ in the diet supplied from 1 to 28 days of age. Protein concentration in the small intestine mucosa was determined, and ODC expression at $7,14,21$, and 28 days of age was evaluated by dot blotting. ODC was present in the mucosa of broilers, and the presence of glutamine in the diet increased ODC activation. Glutamine prevented mucosa atrophy by stimulating protein synthesis, and was effective against the effects of feed restriction. Dot blotting can be used to quantify ODC expression in the intestinal mucosa of broilers.

\section{INTRODUCTION}

Functional development of the intestines is essential for successful poultry production. It has been shown that mammals and birds present intestinal mucosa atrophy when submitted to feed restriction (Palo et al., 1995; Fischer da Silva, 2001). Fasting, even for a small period of time, may interfere with cell synthesis, and negatively affect bird growth. Feed ingredients contain compounds that directly stimulate the growth of the intestinal mucosa. These can also be converted into trophic factors after digestion (Uni \& Sklan, 1998, Tarachai \& Yamauchi, 2000).

Biogenic amines, especially polyamines, are among growth factors present in the intestinal mucosa (Sipponen et al.,1976). According to Janne et al. (1991), these are essential components for cellular growth and differentiation. The polyamines spermine, spermidine, and their diamine precursor, putrescine, are aliphatic cations, which are essential for normal physiology and growth of virtually every cell (Yang, 1984). Putrescine formation depends on the decarboxylation of ornithine by the action of the enzyme ornithine decarboxylase (ODC) (Luck and Baylin, 1980). This enzyme is found in all eucaryotic cells, and the levels of its products are highly regulated, having an important role in the initiation of cell proliferation and mitochondrial function (Tabor and Tabor, 1984). The increase in ODC activity is one of the first biochemical events associated to the induction of proliferative cells (Wang et al., 1996).

Increased ODC activity after trophic stimulation or during tissue regeneration has been observed in different types of tissues (Tabor 
Fischer da Silva AV, Borges SA, Maiorka A, Givisiez PEN, Rocha C, Macari M

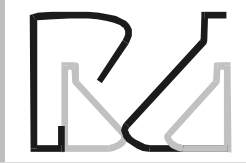

and Tabor, 1984). Indeed, it was reported that rats submitted to fasting had increased ODC activity in the mucosa of the small intestine and colon during refeeding (Madsen et al., 1996).

Simple amines and amino acids may stimulate ODC activity in the mucosa. Evidences show that asparagine, glutamine, serine, and glycine, present in the lumen, stimulate mucosal growth by inducing the expression of the ODC gene (Wang et al.,1996).

The present study evaluated the effects of diets supplemented with glutamine on the expression of intestinal mucosa ornithine decarboxylase in the of broiler chickens submitted to early feed restriction (7 to 14 days of age).

\section{MATERIAL AND METHODS}

Day-old male Cobb chicks ( $n=640$ ) were randomly distributed in floor pens $(1.50 \times 3.50 \mathrm{~m})$. Birds were fed isocaloric diets containing corn, soybean meal, soybean oil, dicalcium phosphate, limestone, sodium chloride, DL-M ethionine, and mineral and vitamin supplements, according to the guidelines and nutritional requirements published by the NRC (1994). Water was provided ad libitum. From one to six days of age, birds were fed ad libitum diets containing either no glutamine or $1 \%$ glutamine. Quantitative feed restriction at $30 \%$ as compared to the ad libitum fed group was applied from seven to 14 days of age. During this period, birds were divided into four treatments: glutamine supplementation and ad libitum feeding, glutamine supplementation and feed restriction, no glutamine supplementation and ad libitum feeding, and finally no glutamine supplementation and feed restriction. Birds were fed ad libitum thereafter.

Four birds per treatment were submitted to a twelve-hour-fasting, and then sacrificed by cervical dislocation at 7, 14, 21, and 28 days of age. Samples of different segments of the small intestine were collected and identified, fast-frozen in liquid nitrogen, and stored at $-70^{\circ} \mathrm{C}$. Intestinal segments were longitudinally opened and the mucosa was scraped. A pool (mixture) was prepared with four samples from each treatment. Scrapings of each treatment were mixed, weighed, and homogenized, and a mixture was prepared for each intestinal segment (duodenum, jejunum, ileum) at each age $(7,14,21$, and 28 days). Samples were placed in a $50-\mathrm{mL}$ polypropylene tube, and diluted with $20 \mathrm{~mL}$ lysis buffer $(20 \mathrm{mM}$ Tris; 0.05 mM EDTA; $0.05 \mathrm{mM}$ pyridoxal phosphate; $5 \mathrm{mM}$ DTT,
Ornithine Decarboxylase Expression in the Small Intestine of Broilers Submitted to Feed Restriction and Glutamine Supplementatio
$\mathrm{pH}$ 7.4). Homogenization was performed three times (30 s) using an ultra-turrax homogenizer at 20,000 rpm and ice-bath intervals of $30 \mathrm{~s}$. After homogenization, the lysate was sonicated (Sonicador Branson Sonifier 250) for $5 \mathrm{~min}$ and then centrifuged at $30,000 \mathrm{~g}$ for 30 min at $4^{\circ} \mathrm{C}$ using a Himac CR $20 \mathrm{~b} 2$ centrifuge and rotor RPR 20-2 (Hitachi Corp.).The supernatant was transferred to a 15-mL polypropylene tube, and homogenized 10 times with a Potter-Elvehjem homogenizer and ice-bath intervals. Two $300-\mathrm{mL}$ aliquots were taken for protein determination and dot blotting .

Total protein determination was performed according to the microplate method described on the BioRad Protein Dye Assay (BioRad, Hercules CA, USA), based on Bradford (1976). Samples were evaluated in duplicate, and readings were performed at $595 \mathrm{~nm}$.

ODC expression was evaluated by dot blotting using nitrocellulose filters. M embranes were humidified with water for $5 \mathrm{~min}$, and water excess was drained before placing the filters on the BioDot Apparatus (BioRad, Hercules, CA, USA). Samples were prepared as described below and volumes were adjusted to $20 \mathrm{~mL}$, using double-distilled water before being loaded into the BioDot apparatus and vaccum-filtered.

As pure ODC was not available, a reference sample (a pool of duodenum samples collected at 7, 14, 21, and 28 days from birds that were not submitted to feed restriction or were received glutamine in the diet) was used to produce a standard curve of ODC expression. The standard curve was prepared using $10,20,30,40,50$, and $60 \mathrm{mg}$ of total protein loaded to the filter.Densitometer detection limit was also evaluated using increasing amounts of one sample with strong color signal, which was loaded at 10, 20, 30, 40,50 , and $60 \mathrm{mg}$ of total protein. A jejunum sample from 28-day-old birds submitted to feed restriction and with feed supplemented with glutamine was used for that purpose. Pools of remaining samples were loaded at 15,20 , and $30 \mathrm{mg}$ of total protein. After the samples were loaded and vacuum-filtered, the membrane was dried and washed with double-distilled water. Blocking was performed with $20 \mathrm{~mL}$ TBS (10mM Tris, $\mathrm{pH} 8.0$; $0.15 \mathrm{M} \mathrm{NaCl}$ ) containing $5 \%$ skimmed milk and $0.02 \%$ Tween 20 (blocking buffer) for one hour at room temperature and continuous shaking.

The membrane was incubated with anti-ODC mouse monoclonal antibody (Sigma, Saint Louis, MO, USA) diluted 1:500 in $20 \mathrm{~mL}$ blocking buffer for $1 \mathrm{~h}$ at room temperature. Four washings of $5 \mathrm{~min}$ each were performed with TBS-T (TBS added with 0.05\% Tween- 
Fischer da Silva AV, Borges SA, Maiorka A, Givisiez PEN, Rocha C, Macari M
Ornithine Decarboxylase Expression in the Small Intestine of Broilers Submitted to Feed Restriction and Glutamine Supplementatio
20), and one washing of 10 min was performed with TBS. The membrane was incubated for one hour in blocking buffer with alkaline phosphatase-labeled antimouse lgG (01136 Sigma) diluted at 1:5000. Washings were performed as previously described, and the signal was developed by the addition of $20 \mathrm{~mL}$ AP buffer (100 $\mathrm{mM}$ Tris- $\left.\mathrm{HCl} \mathrm{pH} \mathrm{9.5;} 100 \mathrm{mM} \mathrm{NaCl} ; 5 \mathrm{M} \mathrm{m} \mathrm{M} \mathrm{gCl}_{2}\right), 132$ $\mathrm{mL}$ nitro-blue tetrazolium chloride (NBT, $50 \mathrm{mg} / \mathrm{mL}$ in dimethylformamide), and $66 \mathrm{~mL}$ 5-bromo-4-chloro-3indolylphosphate p-toluidine (BCIP, $50 \mathrm{mg} / \mathrm{mL}$ in $70 \%$ dimethyl formamide. The reaction was stopped with $3 \%$ TCA (trichloroacetic acid). The membrane was washed with double-distilled water, and dried at room temperature protected from light. The color signal of the membrane was read at $525 \mathrm{~nm}$ using a densitometer (Shimadzu CS-9301, Shimadzu Corporation, Tokyo, Japan), and the results of the ornithine decarboxylase expression in the small intestine of broilers were expressed in area $\left(\mathrm{mm}^{2}\right)$.

\section{RESULTS AND DISCUSSION}

The area of ODC expression in the jejunum, ileum, and duodenum of chicks at 7 days of age is shown in Figure 1. Birds fed glutamine showed higher ODC expression in the duodenum and jejunum at seven days of age, although expression in the ileum was equivalent between treatments with glutamine. In mammals, Yang et al. (1984) reported an increase in ODC activity of the small intestine mucosa in the first 7 days of lactation, and the authors also observed significant increases in the intestinal weight and spermidine levels in the mucosa during the same period. Maiorka et al. (2000) reported that glutamine supplementation to a corn-soybean meal based diet increased villi size in the duodenum and ileum of broilers during the first seven days of age. However, the mechanism by which glutamine stimulates the proliferation of enterocytes is unclear. Nevertheless, Rhoads et al. (1997) suggested that glutamine is related to two events associated to cell proliferation in the jejunum of swine: increase in $\mathrm{Na}^{+} / \mathrm{H}^{+}$exchange in the plasmatic membrane, and increase of the specific activity of ODC. It also has been suggested that glutamine activates mitogenesis (Blikslager \& Roberts 1997).

At 14 days, higher ODC expression was observed in the duodenum and the ileum of feed-restricted birds receiving diets supplemented with glutamine (Figure 2). During the first weeks of age, glutamine had a higher impact on intestinal mucosa growth, increasing villi height in the duodenum and the ileum (Fischer da Silva 2001). During this period, birds need more available energy and protein for cell multiplication and production of digestive enzymes.

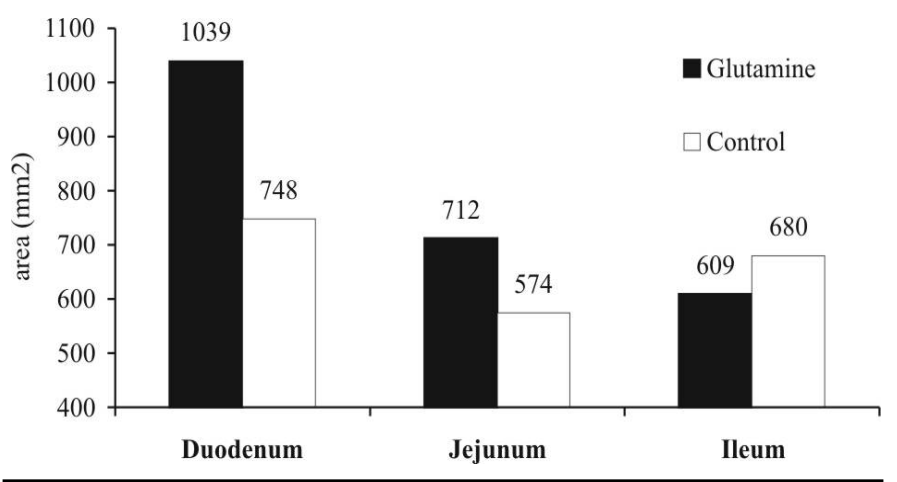

Figure 1 - ODC expression in the small intestine of broilers at 7 days of age. The area readings are indicated.

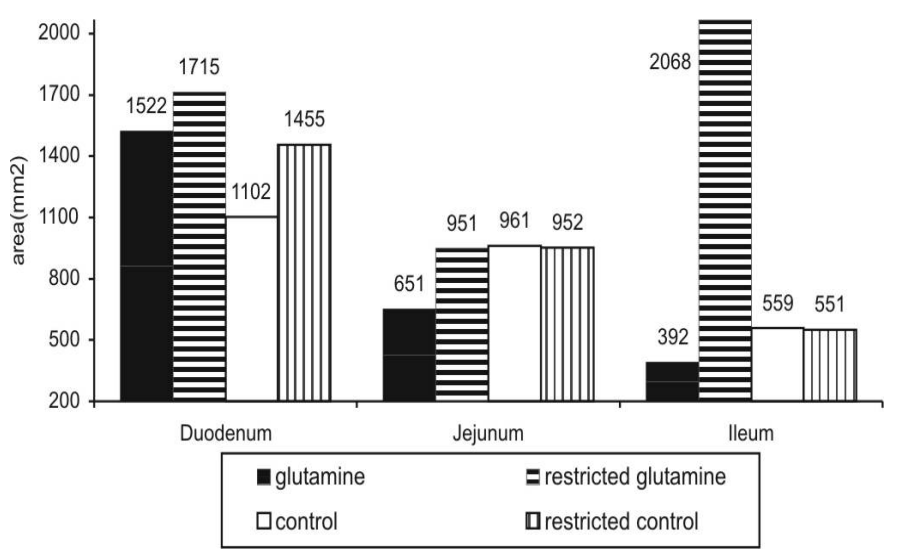

Figure 2 - ODC expression in the small intestine of broilers at 14 days of age. The area readings are indicated.

The gastrointestinal tract grows rapidly after hatching, mainly during the first two weeks of life. A significant increase in intestinal mucosa growth indicates intestinal maturation (Senkoyiu \& Janssen, 1988). A marked increase in ODC activity and polyamine biosynthesis was observed in the intestinal mucosa of newly born rats up to the third week of life. In that period, the intestinal mucosa cells changed rapidly, from fetal to adult animal cells (Luck et al., 1980). According to this author, the increase in ODC activity is the result of increased biosynthesis of polyamines, which can effect intestinal mucosa maturation and regeneration. Similarly, Yang et al. (1984) observed that, during injury and sloughing of the intestinal mucosa, there was fast regeneration and proliferation of the intestinal mucosa following increased ODC activity.

The amount of ingested food influences greatly the 
Fischer da Silva AV, Borges SA, Maiorka A, Givisiez PEN, Rocha C, Macari M development of mucosa and other structures of the gastrointestinal tract (Steiner et al., 1968). Rats submitted to a six-day fasting presented $53 \%$ decrease in small intestine weight as compared to $32 \%$ decrease in total body weight. M oreover, cell numbers in the intestinal mucosa were reduced, as well as RNA, protein and water levels in the intestinal mucosa cells as compared to these levels in other mucosa cells. Shamoto et al. (1999) reported decreased villi height and cell proliferation in the crypts when broilers were submitted to fasting, although birds recovered during re-feeding. Recovery after fasting is highly dependent on the presence of nutrients in the intestinal lumen (Tarachai \& Yamauchi, 2000).

At 21 days of age, the mucosa of feed-restricted birds supplemented with glutamine showed higher ODC expression in the duodenum, followed by the jejunum, and lastly the ileum (Figure 3). At 28 days, higher ODC expression was observed in the duodenum of non-feed restricted birds fed the diet supplemented with glutamine (Figure 4). In the jejunum and the ileum, higher ODC expression was verified in the feedrestricted birds not supplemented with glutamine.

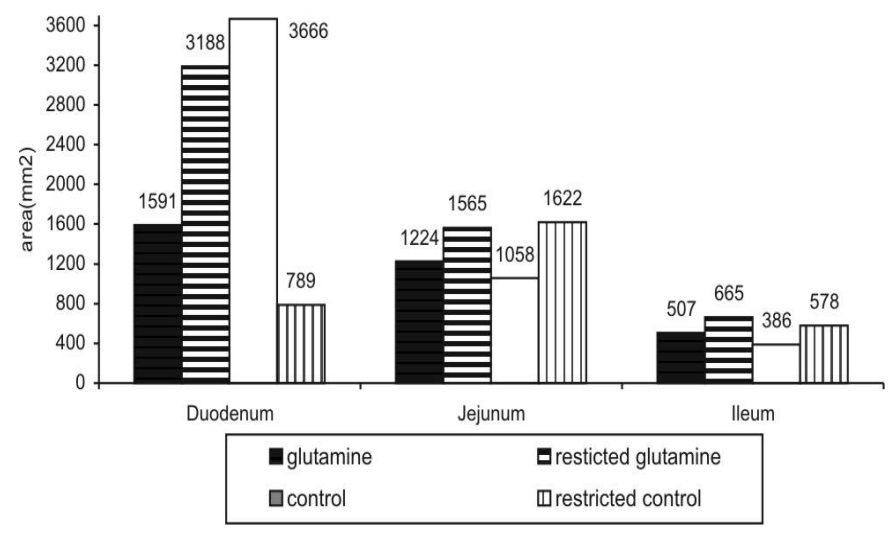

Figure 3 - ODC expression in the small intestine of broilers at 21 days of age. The area readings are indicated.

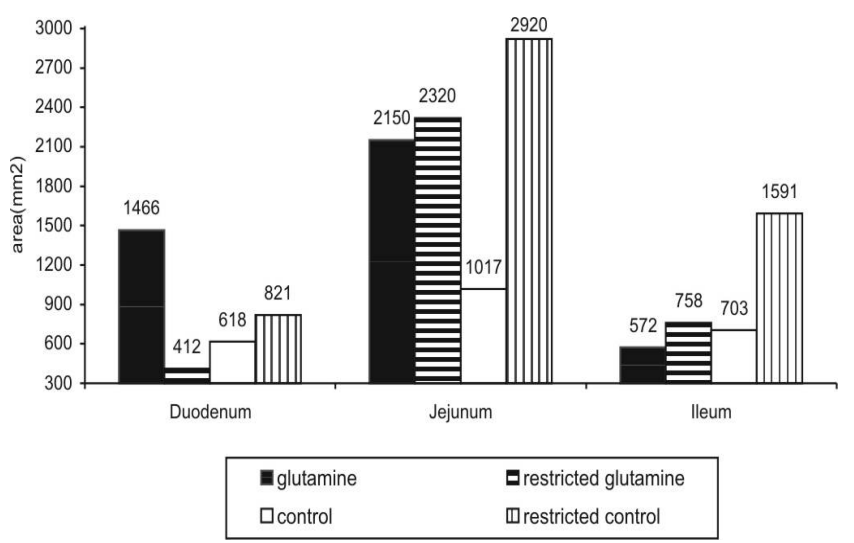

Figure 4 - ODC expression in the small intestine of broilers at 28 days of age. The area readings are indicated.
Ornithine Decarboxylase Expression in the Small Intestine of Broilers Submitted to Feed Restriction and Glutamine Supplementatio

\section{CONCLUSIONS}

Glutamine supplemented diets increased the expression of ornithine decarboxylase in the intestinal mucosa of broilers.

Glutamine supplementation prevented deleterious reduced intestinal mucosa atrophy in feed-restricted birds through the stimulation of protein synthesis.

\section{REFERENCES}

Blikslager AT, Roberts C. M echanisms of intestinal mucosal repair. Journal American Veterinary of Medical Association 1997; 211:1437-1441.

Bradford MM. A rapid and sensitive method for the quantitation of microgram quantities of protein utilizing the principle of proteindye binding. Analytical Biochemistry 1976; 72:248-254.

Fischer da Silva AV. Efeitos da restrição alimentar precoce e da glutamina no desempenho e na mucosa intestinal em frangos [tese]. Jaboticabal(SP): Universidade Estadual Paulista; 2002.

Janne J, Alhonen L, Leinonen P. Polyamines: from molecular biology to clinical applications. Annals of Medicine 1991; 23:241-259.

Luck GD, Morton JJ, Baylin SB. Ornithine decarboxylase is important in intestinal mucosa maturation and recovery from injury in rats. Science 1980; 210:195-198.

Macari M. Mecanismos de proliferação e reparação da mucosa gastrointestinal em aves. Anais do $1^{\circ}$ Simpósio de coccidiose e enterite;1995; Campinas-SP. Brasil.

Madsen KL, Brockway PD, Johnson LR, Hardin JA, Gall GD. Role of ornithine decarboxylase in enterocyte mitochondrial function and integrity. American Journal of Physiology 1996; 270:G789-797.

M aiorka A, Fischer da Silva AV, Santin E, Borges SA, Boleli IC, M acari $M$. Influência da suplementação de glutamina sobre o desempenho e o desenvolvimento dos vilos e criptas do intestino delgado de frangos. Arquivo Brasileiro de Medicina Veterinária e Zootecnia 2000; 52:487-490.

National Research Council. Nutrient requirements of poultry. Washington: National Academy Press; 1994.

Palo PE, Sell JL, Piquer FJ, Soto-Salanova MF, Vilaseca L. Effect of early nutrient restriction on broiler chickens. 1. Performance and development of the gastrintestinal tract. Poultry Science 1995; 74:88-101.

Rhoads JM, Argenzio RA, Chen W, Rippe RA, Westwick JK, Cox AD, Berschneider HM, Brenner DA. L-glutamine stimulates intestinal cell proliferation and activates mitogen-activated protein kinases. American Journal of Physiology 1997; 272:G943-G953.

Senkoyiu N, Janssen WM. The effect of age, basic feed, fat type, and inclusion levels upon apparent metabolizable energy values in 


\section{Fischer da Silva AV, Borges SA, Maiorka A, Givisiez PEN, Rocha C, Macari M}

chicken feeds. Proceedings of the $18^{\text {th }}$ World's Poultry Congress; 1988; Nagoya, Japan. p.784-786.

Shamoto K, Yamauchi K, Kamisoyama H. M orphological alterations of the duodenal villi in chicks refed rice bran or grower mash fasting. Japanese Poultry Science 1999; 36:38-46.

Sipponen P, Hakkiluoto A, Kaliama TV, Siurala M. Selective loss of parietal cells in the gastric remnant following antral resection. Journal of Gastroenterology 1976; 11:813-816.

Steiner M, Boughes HR, Freedman LS, Gray JJ. Effect of starvation on the tissue composition of the small intestine of the rat. American Journal of Physiology 1968; 215:75-77.

Tabor CW, Tabor H. Polyamines. Annual Revivew of Biochemistry 1984; 53:749-790.

Tarachai P, Yamauchi K. Effects of luminal nutrient absorption, intraluminal physical stimulation, and intravenosus parenteral alimentation on the recovery responses of duodenal villus morphology following feed withdraw in chickens. Poultry Science 2000; 79:1578-1585.

Uni Z, Platin R, Sklan D. Cell proliferation in chick intestinal epithelium occurs both in crypts and along the villus. Journal Comparative Physiology 1998; 168:241.

Wang JY, Viar MJ, Blanner PM, Johnson LR. Expression of the ornithine decarboxylase gene in response to asparagine in intestinal epithelial cells. American Journal of Physiology 1996; 271:G164G171.

Yang P, Baylin SB, Luck GD. Polyamines and intestinal growth: absolute requirement for ODC activity in adaptation and lactation. American Journal of Physiology 1984; 247:G553-G557. 